\author{
Ewa Szewczyk \\ University of Zielona Góra, Poland \\ ORCID: 0000-0002-2980-6564 \\ eszewczyk@uz.zgora.pl
}

\title{
Humane Protection of Animals Against the Effects of Fireworks Displays
}

\author{
Humanitarna ochrona zwierząt przed skutkami \\ pokazów fajerwerków
}

\begin{abstract}
This article is of a scientific and research nature. Its subject is the humane protection of animals, expressly declared by the Polish legislator in the provisions of the Animal Protection Act, as regarded in the context of wide access to individual use of fireworks by private persons. The author seeks an answer to the question whether the legislator's high-sounding declarations expressed in the Animal Protection Act, providing for humane protection of animals in Poland, are reflected in respective national or local regulations which would make it possible for the owners or guardians of animals to protect them against the effects of fireworks, especially against noise. The aim of the research is to indicate who, if it has not already been done by the national legislator, is authorised to issue regulations limiting the use of fireworks, in a manner modelled for example on Australian solutions, where displays can be organised by licensed, authorised companies, or in a manner whereby the owner or keeper of the animal is informed in advance by an announcement on the Internet or in a local newspaper of the planned place and date of the pyrotechnic show, so that he or she can provide protection for his or her animal by moving away from the venue in advance. The analysis of national solutions aims to indicate how the shortcomings in this area should be addressed by the regional legislator.
\end{abstract} show

Keywords: humane protection of animals; Animal Protection Act; fireworks displays; pyrotechnic

CORRESPONDENCE ADDRESS: Ewa Szewczyk, PhD, Dr. habil., Associate Professor, University of Zielona Góra, Faculty of Law and Administration, Plac Słowiański 9, 65-069 Zielona Góra, Poland. 


\section{INTRODUCTION}

In recent years there has been a clear public interest in the humane treatment of animals. There is no doubt that humane treatment of animals translates into the proper treatment of all living beings. More and more people react to manifestations of cruelty to animals, quite commonly referred to - following the words of St. Francis of Assisi - as our lesser brothers. This applies not only to domestic pets, but also to farm animals.

The humane protection of animals in Poland encompasses all principles representing the attitude of people towards animals. ${ }^{1}$ This protection stems from ethical motives that prohibit humans from inflicting unnecessary suffering on animals as living beings. ${ }^{2}$ In general, it can be said that humaneness manifests itself in caring for the welfare of the animal. ${ }^{3}$

Legal regulations providing for humane protection of animals date back to as early as the 1920s. In the provisions of the Decree of the President of the Republic of Poland of 22 March 1928 on the protection of animals, ${ }^{4}$ the Polish legislator established a general prohibition on the abuse of all animals (domestic, tame, fowl, fish, amphibians) and inflicting unnecessary suffering on them under pain of criminal liability.

The humane protection of animals in Poland is not a constitutional right. Legal scholars classify the principle of the humane protection of animals as a part of environmental law. ${ }^{5}$ It is established by provisions of the Act of 21 August 1997 on animal protection ${ }^{6}$ which already in Article 1 (1) states that an animal is a living being, "Man owes it respect, protection and care". Article 5 APA unequivocally states that "Every animal requires humane treatment". At the same time, Article 4 (2) APA explains that humane treatment should be understood as "treatment which takes into account the needs of the animal and ensures its care and protection". In turn, according to Article 33 (1a) APA "killing of animals may only be carried out in a humane way".

The subject of this study is humane protection of animals, as expressly declared by the Polish legislator. The author analysed it using the legal and dogmatic and (to some extent) comparative approach in the context of providing animals with

${ }^{1}$ For more, see Z. Gądzik, Ochrona humanitarna zwierzat utrzymywanych w ogrodach zoologicznych, "Studia Prawnicze KUL" 2019, no. 2, p. 113 ff.

2 P. Paleń, Wybrane aspekty prawne ochrony zwierzat gospodarskich w Polsce, "Kortowski Przegląd Prawniczy" 2017, no. 2, p. 1.

${ }^{3}$ E. Łętowska, M. Namysłowska, M. Grochowski, A. Wiewiórowska-Domagalska, Prawo UE o uboju zwierząt i jego polska implementacja: kolizje interesów i ich rozwiązywanie (cz. II), "Europejski Przegląd Sądowy" 2013, no. 12, pp. 4-9.

4 Journal of Laws 1928, no. 36, item 332; consolidated text, Journal of Laws 1932, no. 42, item 417.

${ }^{5}$ M.G. Węgrowski, Przestępstwa przeciwko humanitarnej ochronie zwierząt, LEX/el. 2009.

${ }^{6}$ Consolidated text, Journal of Laws 2020, item 638, hereinafter: APA. 
protection against explosions of fireworks, including noise. To this end, legislation at both national and local level has been analysed. The discussion has been augmented by an indication of the solutions adopted for the individual use of fireworks by private persons in other countries both within and outside Europe.

The aim of this study is to answer the question whether the above-mentioned high-sounding declarations of the legislator as expressed in the Animal Protection Act, providing for humane protection of animals in Poland, are reflected in respective national or local regulations which would make it possible for the owners or guardians of animals to protect them against the effects of fireworks. The analysis of national solutions - which should take into account the applicable standards, rules and norms ${ }^{7}$ - aims to indicate how the deficiencies in this area should be supplemented by the regional legislator.

\section{EFFECTS OF FIREWORKS ON ANIMAL BEHAVIOUR}

For many people, fireworks (by which the author of this study means various pyrotechnics commonly available in the market, such as flares, fireworks, firecrackers, etc.) are an inseparable part of festive celebrations. However, it should be noted that the use of fireworks is equivalent to the explosion of sparks and flames, emission of smoke and, in particular, generation of noise, the level of which may exceed that of a jet aircraft take-off. ${ }^{8}$ The smoke from fireworks contains harmful particulates that are toxic to both animals and humans when inhaled.

It is well known that cats and dogs have much better and more sensitive hearing than humans. If they are close to where firecrackers or fireworks explode they may be at risk of irreversible hearing loss. The panic of dogs when fireworks go off is a result of them not being able to find shelter or escape the noise. Birds in such situations become panicked, disoriented and crash into buildings or other obstacles. ${ }^{9}$ Wild animals are hastily fleeing their habitats. Pets try to find a hiding place, for example in the basement, bathroom or closet. It is common for pets to run away in an uncontrolled manner, sometimes running amok for miles, unable to find their way back. Some animals get heart attacks. Many of them suffer from excessive

${ }^{7}$ For more on a coherent image of law, see A. Bröstl, A Jigsaw Puzzle for Rainy Days - How to Put Together the Pieces: Sources of Law, Forms of Law, Principles, Standards, Rules and Norms - to Get a Consistent Picture of Law, "Studia Iuridica Lublinensia" 2020, vol. 29(3), pp. 13 ff.

${ }^{8}$ Animal Ethics, How fireworks harm nonhuman animals, www.animal-ethics.org/how-fireworks-harm-nonhuman-animals [access: 24.01.2021].

${ }_{9}$ On the night of 31 December 2010, approximately 4,000-5,000 red-winged blackbirds fell to the ground and died in Beebe, Arkansas. See AVMA, Mass bird deaths in Arkansas explained, 18.03.2011, www.avma.org/javma-news/2011-04-01/mass-bird-deaths-arkansas-explained [access: 24.01.2021]. 
salivation, tachycardia, urinate and defecate, or have gastrointestinal disorders. ${ }^{10}$ For all these "lesser brothers" the experience of the noise caused by fireworks is a trauma, and on subsequent occasions they may manifest a phobia.

By the way, loud explosions caused by fireworks are annoying not only for animals. Sensory overload makes them especially stressful also for children, the elderly, and autistic people.

\section{SOLUTIONS TO THE ISSUE OF FIREWORKS IN OTHER COUNTRIES}

Of particular interest is the solution to the discussed problem adopted in the Italian town of Collechio in the province of Parma, where since 2015 a "quiet fireworks show" has been held instead of the traditional fireworks display. ${ }^{11}$ The fireworks are provided by the Italian company Setti Firework, which specializes in the use of new pyrotechnic technologies, thanks to which the visual effects are spectacular with a limited acoustic impact. ${ }^{12}$

The British Veterinary Association, being aware of the effects of fireworks on animals, has proposed normative regulation of the noise emitted by fireworks displays. This would be limited to 97 decibels, and the level of emitted noise would have to be indicated on the product placed on the market so that potential buyers could make informed purchase decisions. ${ }^{13}$

Some countries provide for mandatory notification of the intention to hold a fireworks display. For example, in the Isle of Man, those planning private shows must notify the fire department of the location, date and time of the event, and then post these details in the local newspaper at least 10 days in advance. ${ }^{14}$

In many countries, the use of fireworks is regulated by local law. In Belgium, for example, around $14 \%$ of all municipalities have introduced a complete ban on using fireworks. Similarly, in Canada, eight municipalities have passed orders banning fireworks. These are Edmonton, Medicine Hat, Red Deer, Lethbridge and Calgary.

${ }^{10}$ For more on this, see the results of research on the behaviour of animals in Erfurt Zoo observed during firework explosions: A. Rodewald, U. Gansloßer, T. Kölpin, Influence of Fireworks on Zoo Animals: Studying different Species at the Zoopark Erfurt during the Classic Nights, "International Zoo News" vol. 61(4), pp. 264-271.

${ }^{11}$ S. Yin, 'Quiet Fireworks' Promise Relieffor Children and Animals, 30.06.2016, www.nytimes. com/2016/07/01/science/july-4-fireworks-quiet.html [access: 24.01.2021].

12 See SETTI Fireworks, https://setti.it [access: 24.01.2021].

13 BVA position on the use and sale of fireworks, www.bva.co.uk/media/3103/bva-policy-position-on-the-use-and-sale-of-fireworks-exec-summary.pdf [access: 24.01.2021].

${ }^{14}$ Isle of Man firework laws to be reviewed amid animal welfare concerns, 21.02.2020, www. bbc.com/news/world-europe-isle-of-man-51579435 [access: 24.01.2021]. 
In Australia, as a rule, both the sale of fireworks and their use by private individuals have been prohibited since $2009 .{ }^{15}$ Holding a fireworks show to add splendour to a private event is only possible with a professional licensed company. ${ }^{16}$ For information purposes, a list of approved pyrotechnic display companies is posted on the Internet. This allows any pet guardian or owner to avoid areas where fireworks displays are held.

Another country where private use of fireworks is completely banned is Chile. They can only be enjoyed at public shows. ${ }^{17}$

In many parts of the world, including Canada and Australia, prohibitions on the use of fireworks are not driven by animal welfare considerations but first and foremost by other factors, such as fire hazards and accidents and related human limb injuries. ${ }^{18}$

\section{USE OF FIREWORKS IN POLAND}

\section{National legislation}

In Poland, there are no nationwide laws prohibiting the use of fireworks. In this respect, one can only refer to the provisions of Article 30 (1) (12) and Article 30 (1) (14) of the Act of 28 September 1991 on forests, ${ }^{19}$ which stipulates that it is forbidden to disturb animals or make noise in forests. It can be inferred from this provision that setting off fireworks in forests is forbidden, as their use undoubtedly leads to noise and frightening of animals, especially wild animals.

At the same time, there are no nationwide regulations that indicate that the use of pyrotechnic products on private property is not permitted. The only limitation in this area results from Article 51 (1) of the Code of Minor Offences, ${ }^{20}$ according to which anyone who disturbs peace, public order, rest at night or causes disorder in a public place by shouting, making noise, raising an alarm or any other behaviour shall be subject to penalty of arrest, restriction of liberty or a fine. Respecting the right to rest,

${ }^{15}$ Fireworks regulations - impact: case studies, 3.11.2020, www.gov.scot/publications/impact-fireworks-regulations-case-studies/pages/7 [access: 25.01.2021].

${ }^{16}$ Applying for a fireworks event permit, www.dmp.wa.gov.au/Dangerous-Goods/Applying-fora-fireworks-event-5447.aspx [access: 25.01.2021].

17 Where are Fireworks Illegal?, www.fireworkscrazy.co.uk/where-are-fireworks-illegal [access: 25.01.2021].

${ }_{18}$ Z. Laing, As regulations end for firework sales, city staff recommend continuing ban, 2019, https://calgaryherald.com/news/local-news/as-regulations-end-for-firework-sales-city-staff-recommend-continuing-ban [access: 24.01.2021].

${ }_{19}$ Consolidated text, Journal of Laws 2020, item 6, as amended.

${ }^{20}$ Act of 20 May 1971 - Code of Minor Offences (consolidated text, Journal of Laws 2019, item 821 , as amended). 
companies that distribute pyrotechnics recommend using them to celebrate private events (such as wedding parties) before 10 p.m.

\section{Local regulations}

\subsection{Enforcement regulations of municipal councils}

For some time now, many municipal councils have been making efforts to limit, and often completely ban, the use of pyrotechnics within a municipality. Resolutions passed in this respect were based on Article 40 (3) of the Act of 8 March 1990 on municipal self-government, ${ }^{21}$ treating the provisions contained therein as enforcement regulations. Pursuant to this provision, "Within the scope not regulated in separate acts or other universally binding regulations, the municipal council may pass enforcement regulations if it is necessary for the protection of life or health of citizens and for the assurance of public order, peace and security". These resolutions introduced bans on the use of pyrotechnics which are commonly associated with different types of fireworks. In many cases, they were repealed in a supervisory mode by voivodes or administrative courts.

For example, in April 2020, the Municipal Council of Świeradów-Zdrój passed a resolution in which it established a year-round ban on setting off fireworks, firecrackers and other pyrotechnic materials, especially due to the fact that patients staying at the health resort expect peace and quiet, additionally pointing to the threat caused by the discharge of fireworks or firecrackers to pets, wild animals and animals that go into hibernation in winter. ${ }^{22}$ However, in May 2020 the Voivode of the Lower Silesian Voivodeship invalidated this resolution. ${ }^{23}$ In the supervisory decision, the Voivode questioned the legality of these provisions, indicating that they had not specified any dangers that could have been averted by the application of these enforcement regulations.

The analysis of the rationale for the supervisory decision of the Voivode leads to the conclusion that one cannot agree with the argumentation contained therein, however, the very conclusion of the decision is in line with the law. The statutory authorisation to enact enforcement regulations takes the form of a norm of

${ }^{21}$ Consolidated text, Journal of Laws 2020, item 713, as amended, hereinafter: AMSG.

22 A similar resolution was adopted by the Municipal Council of Karpacz on 19 December 2018. It was also cancelled by the Voivode of the Lower Silesian Voivodeship.

${ }^{23}$ Supervisory Decision no. NK-N.4131.138.2.2020.MF of the Lower Silesian Voivode of 13 May 2020 declaring the invalidity of Resolution no. XXVI / 121/2020 of the Świeradów-Zdrój City Council of 24 April 242020 on the prohibition of firing fireworks, firecrackers, fireworks and other pyrotechnic materials throughout the year in the city of Świeradów-Zdrój (Official Journal of the Lower Silesia Voivodeship 2020, item 3219), https://edzienniki.duw.p1/legalact/2020/3219 [access: 10.07.2021]. 
legislative competence, ${ }^{24}$ i.e. one authorising the establishment of a general and abstract norm. ${ }^{25}$ The enforcement regulations - by the will of the legislator - are to be treated as acts of local law. These, in turn, in accordance with Article 87 (2) of the Constitution of the Republic of Poland, ${ }^{26}$ belong to the sources of universally binding law. Thus, they are, by the will of the constitutional and the ordinary legislator, law-making and not law-applying acts. ${ }^{27}$ Lawmaking, on the other hand, unlike its application, does not require either the establishment of a factual situation justifying the issuance of a given act, nor provision of evidence that this factual situation occurred, nor performing a process of subsumption, which - as results from the rationale for the supervisory decision of the Voivode of the Lower Silesian Voivodeship - was required by this body. The condition for the issuance of enforcement regulations, which are law-making acts, ${ }^{28}$ shall not be demonstrating by means of evidence that a situation of a threat to any of the legally protected goods has actually arisen. A hypothetical, i.e. abstract, possibility of a threat to any of these goods and the absence of legal regulations aimed at averting threats to these goods in this respect is sufficient.

The supervisory decision of the Voivode of the Lower Silesian Voivodeship deserves approval, albeit not for the reasons stated in its rationale. Enforcement regulations may not be issued when the subject matter is regulated by acts or other universally binding provisions. ${ }^{29}$ The Voivode of the Lower Silesian Voivodeship alleged that the resolution of the Municipal Council of Świeradów-Zdrój failed to meet the premise of a "loophole in the law". This allegation is misconceived since there are no provisions in the system of universally applicable law which would prohibit the disturbance of public peace and order by "setting off fireworks". Using the terminology of criminal law, one can say that the essence of the act consisting in "setting off fireworks" is not prohibited by any provision of universally binding law. What is more, "setting off fireworks" is not only tolerated, but sometimes expected in situations usually defined by norms of customary law to celebrate various ceremonies, both official and private. Therefore, the prohibition of disturbing public order and peace contained in the Code of Minor Offences cannot be

${ }^{24}$ S. Wronkowska, Z. Ziembiński, Zarys teorii prawa, Poznań 2001, p. 144.

${ }_{25}$ B. Dolnicki, [in:] Ustawa o samorzadzie gminnym. Komentarz, ed. B. Dolnicki, Warszawa 2010, p. $620 \mathrm{ff}$.

${ }^{26}$ Constitution of the Republic of Poland of 2 April 1997 (Journal of Laws 1997, no. 78, item 483, as amended). English translation of the Constitution at: www.sejm.gov.pl/prawo/konst/angielski/ kon1.htm [access: 10.08.2021]

${ }^{27}$ For more, see M. Szewczyk, Stanowienie przepisów gminnych, Warszawa 1991, p. 3 ff.; eadem, Normatywny charakter przepisów porządkowych, [in:] Myśl Mariana Zimmermanna a wspótczesne prawo administracyjne, eds. L. Staniszewska, M. Szewczyk, M. Zimmermann, Warszawa 2020, p. 35 ff.

${ }^{28}$ H. Rot, [in:] H. Rot, K. Siarkiewicz, Zasady tworzenia prawa miejscowego, Warszawa 1994, p. $13 \mathrm{ff}$.

29 E. Ochendowski, Prawo administracyjne. Część ogólna, Torun 2013, p. 138. 
construed in such a way that it generally covers "setting off fireworks", regardless of the circumstances.

The conclusion of the supervisory decision of the Voivode of the Lower Silesian Voivodeship is to be endorsed since the provision of Article 40 (3) AMSG does not include within its scope the authority of municipalities to pass enforcement regulations for the protection of life or health of animals. The provision of Article 40 (3) AMSG authorises the establishment of prohibitions and restrictions for the sake of protecting human health and life. That authorisation cannot be used to infer - on the basis of the a maiori ad minus or a minori ad maius rule - the authorisation to lay down prohibitions and restrictions for the protection of animal life and health.

By the way, it is undoubtedly to be applauded that the local legislator (the municipal council) noticed the problem of inadequate protection of animal rights while trying to protect people from the effects of fireworks. The provision of Article 40 (3) AMSG may have been even consciously invoked when restrictions on setting off fireworks were introduced because the legislator realised that this provision did not provide a sufficient legal basis for the municipal council to adopt a ban in this scope. When passing resolutions in the form of enforcement regulations, municipal councils are guided by the generally available (e.g., on the CBOSA website) jurisprudence by administrative courts in similar types of cases. The analysis of the existing jurisprudence leads to the conclusion that in many cases administrative courts repealed enforcement regulations limiting the use of fireworks in a municipality. In many of their judgements, they have shown - by raising arguments related to the existence of Article 51 (1) of the Code of Minor Offences - that Article 40 (3) AMSG cannot constitute a legal basis for prohibiting and penalising every use of fireworks in the municipality. ${ }^{30}$ For example, the Voivodeship Administrative Court in Kielce, in its judgement of 29 November $2017^{31}$ (II SA/Ke 588/17), declared invalid the resolution of the Municipal Council in Końskie of 28 October 2015 no. $\mathrm{XV} / 122 / 2015$ on the prohibition of fireworks, firecrackers and other pyrotechnic materials. A similar judgement was issued by the Voivodeship Administrative Court in Łódź on 16 June $2014^{32}$ in relation to the resolution of the Municipal Council in Łask of 23 February 1999.

In the light of the above considerations, which indicate that the national legislator has not yet regulated the use of fireworks by private persons from the point of view of its impact on animal welfare, and the local legislator in the form of

${ }^{30}$ See judgement of the Supreme Administrative Court of 4 June 2008, II OSK 268/08, LEX no. 465053; judgement of the Voivodeship Administrative Court in Poznań of 18 May 2011, IV SA/Po 213/11, LEX no. 995398; judgement of the Voivodeship Administrative Court in Poznań of 14 December 2014, IV SA/Po 1009/11, LEX no. 1154830; judgement of the Voivodeship Administrative Court in Kielce of 29 November 2017, II SA/Ke 588/17, LEX no. 2411671.

${ }^{31}$ II SA/Ke 588/17, LEX no. 2411671.

${ }^{32}$ III SA/Łd 355/14, CBOSA. 
municipal councils is not authorised to enact laws in this respect, one may wonder whether there is a loophole in the law, despite the fact that according to Article 1 (1) APA "an animal, as a living being capable of experiencing suffering, is not a thing. Man owes it respect, protection and care", and, pursuant to Article 5 APA, "every animal shall be treated humanely", i.e. treated in a manner that "takes into consideration the needs of the animal and ensures its care and protection".

\subsection{Regional regulations}

In addition to municipal councils, the legislator has vested in voivodes authority to enact local laws at a regional level. According to Article 60 (1) of the Act of 20 January 2009 on the voivode and government administration in the voivodeship: ${ }^{33}$ "Within the scope not regulated in universally binding regulations, the voivode may pass enforcement ordinances if it is necessary for the protection of life, health or property and for the assurance of public order, peace and security".

Comparison of the limits of statutory authorisation to enact regulations in the scope of goods protected under Article 40 (3) AMSG with Article 60 (1) AGAV leads to the conclusion that the entity authorised to regulate the use of fireworks due to protection of animal rights is the voivode. The provision of Article 60 (1) AGAV does not limit the scope of protection referred to therein to humans, stating in general terms: "protection of life", "health".

An example of an authority that has addressed this issue in its ordinance is the Voivode of the Lubelskie Voivodeship, who on 21 December 2020 issued an ordinance banning the use of fireworks in public space. However, it is apparent from its wording that, in laying down the temporary prohibitions therein, the Voivode was guided by considerations of protecting human life and health and not those of animals.

\section{CONCLUSION}

The legally permissible freedom to enjoy fireworks displays, which can potentially explode every day on private properties in Poland, stands in stark contrast to the provisions of the Animal Protection Act, from which the high-sounding declarations of the legislator concerning the humane treatment of animals are derived. Currently, as there are no adequate regulations both at the national and regional level, it is impossible for an owner or a guardian of an animal to fulfil the provisions of Article 1 (1) APA which states that they owe it respect, protection and care.

${ }^{33}$ Consolidated text, Journal of Laws 2019, item 1464, hereinafter: AGAV. 
The lack of statutory (nationwide) regulation of the use of fireworks, through e.g. the introduction of a ban on their use by private persons (taking into account that this ban could be lifted after obtaining the permission of the competent authority, or allowing the authorisation of such events if organised by authorised companies) makes the basis for regional regulations under Article 60 (1) AGAV particularly important. This provision formulates a statutory authorisation on the basis of which voivodes may issue ordinances regulating the issue in question with a view to protecting animals and not only humans. However, a preliminary analysis of the enforcement provisions enacted by voivodes indicates that so far none of them has taken the legislative initiative to restrict the use of fireworks due to the protection of animals and the requirement of their humane treatment as derived from the Animal Protection Act.

\section{REFERENCES}

\section{Literature}

Bröstl A., A Jigsaw Puzzle for Rainy Days - How to Put Together the Pieces: Sources of Law, Forms of Law, Principles, Standards, Rules and Norms - to Get a Consistent Picture of Law, "Studia Iuridica Lublinensia" 2020, vol. 29(3), DOI: https://doi.org/10.17951/sil.2020.29.3.13-27.

Dolnicki B., [in:] Ustawa o samorządzie gminnym. Komentarz, ed. B. Dolnicki, Warszawa 2010.

Gądzik Z., Ochrona humanitarna zwierząt utrzymywanych w ogrodach zoologicznych, "Studia Prawnicze KUL” 2019, no. 2, DOI: https://doi.org/10.31743/sp.5851.

Łętowska E., Namysłowska M., Grochowski M., Wiewiórowska-Domagalska A., Prawo UE o uboju zwierząt i jego polska implementacja: kolizje interesów i ich rozwiązywanie (cz. II), "Europejski Przegląd Sądowy" 2013, no. 12.

Ochendowski E., Prawo administracyjne. Część ogólna, Torun 2013.

Paleń P., Wybrane aspekty prawne ochrony zwierząt gospodarskich w Polsce, "Kortowski Przegląd Prawniczy" 2017, no. 2.

Rodewald A., Gansloßer U., Kölpin T., Influence of Fireworks on Zoo Animals: Studying different Species at the Zoopark Erfurt during the Classic Nights, "International Zoo News" vol. 61(4).

Rot H., [in:] H. Rot, K. Siarkiewicz, Zasady tworzenia prawa miejscowego, Warszawa 1994.

Szewczyk M. Normatywny charakter przepisów porządkowych, [in:] Myśl Mariana Zimmermanna a wspótczesne prawo administracyjne, eds. L. Staniszewska, M. Szewczyk, M. Zimmermann, Warszawa 2020.

Szewczyk M., Stanowienie przepisów gminnych, Warszawa 1991.

Węgrowski M.G., Przestępstwa przeciwko humanitarnej ochronie zwierząt, LEX/el. 2009.

Wronkowska S., Ziembiński Z., Zarys teorii prawa, Poznań 2001.

\section{Online sources}

Animal Ethics, How fireworks harm nonhuman animals, www.animal-ethics.org/how-fireworks-harm-nonhuman-animals [access: 24.01.2021].

Applying for a fireworks event permit, www.dmp.wa.gov.au/Dangerous-Goods/Applying-for-a-fireworks-event-5447.aspx [access: 25.01.2021]. 
AVMA, Mass bird deaths in Arkansas explained, 18.03.2011, www.avma.org/javma-news/2011-04-01/ mass-bird-deaths-arkansas-explained [access: 24.01.2021].

BVA position on the use and sale of fireworks, www.bva.co.uk/media/3103/bva-policy-position-onthe-use-and-sale-of-fireworks-exec-summary.pdf [access: 24.01.2021].

Fireworks regulations - impact: case studies, 3.11.2020, www.gov.scot/publications/impact-fireworks-regulations-case-studies/pages/7 [access: 25.01.2021].

Isle of Man firework laws to be reviewed amid animal welfare concerns, 21.02.2020, www.bbc.com/ news/world-europe-isle-of-man-51579435 [access: 24.01.2021].

Laing Z., As regulations end for firework sales, city staff recommend continuing ban, 2019, https:// calgaryherald.com/news/local-news/as-regulations-end-for-firework-sales-city-staff-recommendcontinuing-ban [access: 24.01.2021].

SETTI Fireworks, https://setti.it [access: 24.01.2021].

Where are Fireworks Illegal?, www.fireworkscrazy.co.uk/where-are-fireworks-illegal [access: 25.01.2021].

Yin S., 'Quiet Fireworks' Promise Relief for Children and Animals, 30.06.2016, www.nytimes. com/2016/07/01/science/july-4-fireworks-quiet.html [access: 24.01.2021].

\section{Legal acts}

Act of 20 May 1971 - Code of Minor Offences (consolidated text, Journal of Laws 2019, item 821, as amended).

Act of 28 September 1991 on forests (consolidated text, Journal of Laws 2020, item 6, as amended).

Act of 21 August 1997 on animal protection (consolidated text, Journal of Laws 2020, item 638).

Act of 8 March 1990 on municipal self-government (consolidated text, Journal of Laws 2020, item 713 , as amended).

Act of 20 January 2009 on the voivode and government administration in the voivodeship (consolidated text, Journal of Laws 2019, item 1464).

Constitution of the Republic of Poland of 2 April 1997 (Journal of Laws 1997, no. 78, item 483, as amended).

Decree of the President of the Republic of Poland of 22 March 1928 on the protection of animals (Journal of Laws 1928, no. 36, item 332; consolidated text, Journal of Laws 1932, no. 42, item 417).

\section{Case law}

Judgement of the Supreme Administrative Court of 4 June 2008, II OSK 268/08, LEX no. 465053. Judgement of the Voivodeship Administrative Court in Poznań of 18 May 2011, IV SA/Po 213/11, LEX no. 995398.

Judgement of the Voivodeship Administrative Court in Lodz 16 June 2014, III SA/Łd 355/14, CBOSA. Judgement of the Voivodeship Administrative Court in Poznań of 14 December 2014, IV SA/Po 1009/11, LEX no. 1154830.

Judgement of the Voivodeship Administrative Court in Kielce of 29 November 2017, II SA/Ke 588/17, LEX no. 2411671. 
Pobrane z czasopisma Studia Iuridica Lublinensia http://studiaiuridica.umes.pl

Data: 26/04/2023 14:39:30

\begin{abstract}
ABSTRAKT
Niniejszy artykuł ma charakter naukowo-badawczy. Jego przedmiotem jest humanitarna ochrona zwierząt, jasno deklarowana przez polskiego ustawodawcę w przepisach ustawy o ochronie zwierząt, postrzegana w kontekście szerokiego dostępu do indywidualnego korzystania z fajerwerków przez osoby prywatne. Autorka poszukuje odpowiedzi na pytanie, czy górnolotne deklaracje ustawodawcy wyrażone w treści przepisów ustawy o ochronie zwierząt przewidujących humanitarną ochronę zwierząt w Polsce mają odzwierciedlenie w stosownych unormowaniach ogólnokrajowych bądź terenowych, które właścicielom czy opiekunom zwierząt pozwoliłyby zapewnić im ochronę przed skutkami wybuchów fajerwerków, w tym zwłaszcza przed hałasem. Celem przeprowadzonych badań jest wskazanie kto, jeśli nie zrobił tego dotychczas ustawodawca krajowy, jest upoważniony do wydania przepisów ograniczających korzystanie $\mathrm{z}$ fajerwerków, w sposób wzorowany np. na rozwiązaniach australijskich, gdzie pokazy mogą być organizowane przez licencjonowane, upoważnione firmy, bądź w sposób, dzięki któremu właściciel czy opiekun zwierzęcia zostanie wcześniej poinformowany przez ogłoszenie w Internecie czy lokalnej gazecie o planowanym miejscu i terminie pokazu pirotechnicznego, aby mógł on zapewnić swojemu zwierzęciu ochronę, oddalając się wcześniej od miejsca pokazu. Analiza rozwiązań krajowych ma na celu wskazanie, w jaki sposób braki panujące w tym zakresie powinny być uzupełnione przez prawodawcę regionalnego.
\end{abstract}

Słowa kluczowe: humanitarna ochrona zwierząt; ustawa o ochronie zwierząt; pokazy fajerwerków; pokaz pirotechniczny 